\title{
Pension Fund Management and Investment Performance
}

\author{
By \\ Ian Tonks \\ Xfi \\ University of Exeter \\ I.Tonks@exeter.ac.uk
}

September 2005

To appear as Chapter in Oxford Handbook of Pensions and Retirement Income (Oxford University Press)

Ian Tonks is professor of finance at the University of Exeter and director of the Xfi Centre for Finance and Investment. 


\section{Introduction}

Pension schemes may be unfunded or funded. In an unfunded pay-as-you-go scheme, the pension represents a transfer made between the current working population to the current retired population. In a funded scheme the working population make contributions into a pension fund which, during the accumulation phase, grows in value up to retirement. After retirement, the fund enters the decumulation phase and pays out a pension to the retired pensioners for the remainder of their lives. The management of investment funds in these pension schemes is the topic of this paper.

During the accumulation phase, the pension fund will tend to increase in value because of additional contributions made into the fund, and also due to the investment returns generated by the assets in the fund. For example, in a pension scheme that requires annual contributions of $\$ 1,000$ over 40 years, the fund's assets will build up to $\$ 120,800$ in value at retirement if the return on cumulated funds was $5 \%$ per year; but the same contributions over the same period if the rate of return was $6 \%$ would grow to $\$ 154,800$. This simple numerical example illustrates that small changes in the return on assets can have a dramatic impact on the size of the pension fund at retirement, and hence on the pension that ca be paid from this accumulated fund. In practice the returns on pension fund investments will vary every period, hence introducing some risk into the size of the pension fund at retirement, and types of pension schemes differ according to who bears this investment risk.

Private pension schemes can be classified by type in two dimensions: whether the pension is paid on a defined contribution or a defined benefit basis, and whether the pension scheme is constituted on an individual or a group basis. Individual pension schemes are always funded and pay a pension at retirement on a defined contribution basis. This means that the individual receives a pension which depends on the accumulated assets in the fund. Personal pensions in the UK and 401(k) pension plans or individual retirement accounts in the US are examples of such schemes, and individuals may have some choice over the type of investments in the fund. Under any defined contribution scheme, the pensioner bears the risk of fund underperformance. Group pension schemes are arranged for more than one individual, and there may be some sharing across generations of the accumulated assets in the pension fund. In most countries occupational schemes provided by an employer are examples of group pension schemes, and may pay on a defined benefit or a defined 
contribution basis. Papke, Petersen and Poterba (1993) note the shift in the US from defined benefit to defined contribution pension schemes and particularly 401(k) plans. Similarly in the UK there has been a substantial growth in UK individual defined contribution schemes over the last twenty years. According to the Sandler Report (2002) between 1988 and 1995 the share of total pensions assets represented by personal pensions increased from 12 to over 20 per cent.

The return earned by assets in the pension fund depends upon the investment strategy and asset allocation decisions of the pension fund. These investment decisions can be made by individual pension contributors, or delegated to professional fund managers. The purpose of this paper is to analyse the investment management process of funds invested in pension schemes. We will be particular interested in measuring the performance of investment returns earned by pension funds. Although we will consider investment performance within a global context, in fact only a small number of countries have sizeable funded pension schemes. Table 1 shows the stock of pension assets for major developed countries in 1996. The US, UK and Netherlands have large amounts of pension fund assets relative to GDP in their economies, reflecting the importance of funded schemes in these countries. ${ }^{1}$ In contrast major economies such as Japan, France and Germany have a relatively small percentage of pension fund assets, reflecting the fact that these economies' pension schemes are predominantly unfunded pay-as-you-go systems.

In the next section we will discuss the investment management industry in general, and explain how it relates to the pensions management industry. Section 3 explains the measurement of investment returns, and section 4 introduces a number of risk-adjusted performance measures, and section 5 discusses some problems with these measures. Sections 6 and 7 report the results of empirical evidence of pension fund investment performance. Section 8 concludes.

\section{Description of Pensions Management Industry}

\footnotetext{
${ }^{1}$ Palacios and Pallares-Miralles (2000) identify these three countries plus Australia, South Africa, Switzerland and Iceland as being the only countries in the world with private pension fund assets being greater than 50 per cent of GDP. A combination of generous tax allowances on pension contributions [Dilnot and Johnson (1993)] and a liberal regulatory regime for pension investments [Davis (1995)] probably explains the dominance of funded pensions in these countries.
} 
Pension fund management is only one part of the very large global investment management industry, which represents the management of investment portfolios by professional fund managers. ${ }^{2}$ Such delegated portfolio management also includes unit trusts (mutual funds), investment trusts (closed-end funds), investment policies, (life assurance, endowment policies). Franks, Mayer and Da Silva (2003) report that it is estimated that the extent of global assets under external management during 1999 was of the order of $€ 33$ trillion. Table 2 shows the assets under management in seven European countries and the United States. Franks et al report that in all of these countries the amount of assets managed has increased substantially throughout the nineteen nineties. In UK, USA, France, Germany, Netherlands over the period 1994-99 the amount of assets managed more than doubled; net assets of Spanish Institutional investors trebled over the same period; and assets under management in Italy in 1999 were six times greater than in 1994. Davis and Steil (2001) produce similar estimates, and suggest that the recent increase is part of a longer trend of institutionalization of the savings markets around the world. In 1970 the total financial claims of the financial sector was 4 per cent of GDP for the G-7 countries. By 1998 this figure had almost doubled to 7.91 per cent.

In table 2, pension assets are a significant part of the global investment management industry: pension funds, mutual funds, and insurance funds account for roughly equal shares of total assets, though both mutual funds and insurance funds will include some pension savings . Pension funds are relatively important in the UK and the US, and we can see from Table 2 that in the US mutual funds are also important institutional investors, which is not the case for the UK. Table 3 shows the percentage of UK corporate equity owned by institutional investors, and shows that pension funds are major investors in the equity markets, owning about 40 per cent of the UK's equity sector. Table 2 also shows, although France and Germany do not have large funded pension schemes, they have relatively large insurance and mutual fund sectors. It is important to recognize that individuals in different countries may be making provisions for their retirement through other savings vehicles. UCITS (Undertaking for collective investment in transferable securities) are important savings vehicles in France and Germany [Franks et al (2002)]

\footnotetext{
${ }^{2}$ Investment management is also referred to as fund management, asset management, portfolio management and money management.
} 
The difference between pension schemes and other saving vehicles, is the long-term nature of the scheme under which the savings cannot be accessed until retirement. Del Guercio and Tkac (2002) find that the flow of funds into pension funds are less sensitive to past performance, than for mutual funds and suggest that this is because on the long-term nature of pension schemes.

A fund manager is an individual (or company) that performs a range of activities centred around a core service of investing clients' assets, in particular managing an investment portfolio. The client-manager relationship is an example of the principal-agent framework where the client employs a fund manager to invest the client's assets in order to maximise returns for a given level of risk or obtain the lowest level of risk to achieve a targeted return. In terms of mean-variance analysis the objective of the fund manger is to locate the client's portfolio on the efficiency frontier or in the case of active fund management to generate abnormal returns above some benchmark ie to do better than the efficiency frontier. With respect to occupational pension funds Lakonishock, Shleifer and Vishny (1992) refer to a "double agency" problem, since the employee as principal, and who will eventually become the recipient of the pension, delegates pension fund decisions to the company who in turn delegates the investment allocation decisions to a fund manager.

Why does the client delegate investment management to the fund manager? There are two reasons: First the fund manager may have superior investment skills, through information processing abilities. The second reason is due to economies of scale in the fund management process: buying and selling securities may be expensive for a small fund, and pooling these funds under the juristiction of a single fund manager may be efficient. Of course the disadvantage of delegated portfolio management, is that the client needs to monitor the fund manager. Bhattacharya and Pfleiderer (1984) and Stoughton (1993) discuss the structure of fund manager contracts within the context of delegated portfolio management.

There are two basic types of delegated investment management: bespoke and pooled fund management. In a bespoke vehicle the client hires a fund manager to make the investment decisions on its behalf according to some specified mandate and specific return expectation. The fund manager acts as the custodian of the investor's capital, and will typically report back to the client in a personal capacity on a regular basis on the performance of the fund. In a pooled vehicle, the client simple purchases units of a diversified investment from a 
financial institution such as an insurance company, or a unit trust, and this approach involves the commingling of investment capital from many clients. The fund manager will again report back to the client, but in a less personal manner. Not surprisingly the costs of running a bespoke service will be more than the pooled vehicle, and for that reason the bespoke vehicle is only likely to be used by clients with large amounts of funds to be managed. Typical fees charged by fund managers for managing a segregated fund across a nmber of countries is given in Table 4 . The median fee for managing an equity portfolio is about 50 basis points or 0.5 per cent per year of the funds under management.

The fund manager manages the client's investment portfolio, with an appropriate mix of asset classes/ select assets, with the typical objective of maximizing returns subject to a specified level of risk, and will adjust the portfolio through time, as expectations of returns changes. Under pooled fund management, the fund manager sets the long-term policy of the fund, and then investors such as pension funds can choose to purchase shares in this investment vehicle. Under bespoke asset management, the fund manager will agree a long-term policy or strategy with the pension fund, that will involve specifying a relevant benchmark against which the portfolio performance will be judged. Traditionally fund managers were assessed by relation to a peer-group benchmark such as outperforming the median performance of similar funds. However Myners' (2001) reports a long-run trend away from peer-group benchmark to customized benchmarks. This trend reflects trustees increasingly taking asset allocation decisions on the basis of advice from consultants, and then allocating management of a class of assets to a specific fund manager. The customized benchmark for that manager might then be the relevant index for that asset class. Bespoke investment management process is seen as dynamic, with the mandate evolving over time as the performance of the fund or asset class varies, and expectations of future returns change.

Individual pension schemes that have delegated investment management will typically be constituted on a pooled basis, unless the individual is particularly wealthy. The type of fund management chosen for occupational pension schemes will depend in part on the advice given by consultant actuaries, who assess the financial viability of the occupational pension scheme. Under an insured scheme contributions are made into a pooled vehicle, which guarantees to pay a pre-defined benefit at a pre-defined time. The risk of a funding shortfall (ignoring default risk) is borne by the fund manager (typically an insurance company), and not the individual or the corporation. Most small schemes will be run as insured fund 
management. Under a self-administered schemes, where the pension fund sponsors have some control over the investment management, fund management may be outsourced to one or more external managers, or managed in-house. If the performance objectives are met, the pension scheme should meet all actuarially defined future liabilities. The risks of a contribution shortfall are thus borne by both the sponsoring company and by the external fund manager (to the extent that a failure to meet the benchmark will result in a loss of assets under management). A self-administered scheme may either opt to join a pooled investment fund, which typically offers a lower fee structure though no mandate flexibility. Alternatively the fund may be managed on a segregated basis, offering greater mandate flexibility but at a higher price. If the scheme is managed on a segregated basis, the pension fund employs one or more fund managers, who are given a mandate to manage assets against a pre-determined benchmark. This method may be discretionary, whereby the asset composition is left up to the fund manager, or non-discretionary, whereby the trustees decide upon the asset allocation. In the non-discretionary case the pension fund sponsors would typically rely on the advice of consultants (actuaries) on the appropriate asset allocation, and then employ specialist fund managers in different sectors.

Very large pension schemes are typically managed by a team of in-house professionals. This allows the fund complete flexibility in terms of asset/liability matching. However the risk of a contribution shortfall lies solely with the scheme sponsor. Tonks (2005) reports on the distribution of fund managers (external and internal) across 2,175 UK occupational pension funds from 1984-97 in table 5, and provides evidence on the concentration of pension fund management.. The top ranked fund manager (1RMan) managers $10.8 \%$ of observations in the sample, the second ranked managers 5.6\% and the third managers $4.8 \%$, and another 14 fund managers (4RMan-18RMan) manage a total of $23.14 \%$ of observations. 1RMan manages across 244 funds, and $81.04 \%$ of these funds' observations are using 1RMan. There is also a multi-manager category and a change of manager category ( $\triangle \mathrm{Man})$. Most funds use a single fund manager in any quarter, but 659 funds have multiple fund managers at some time, and $29.07 \%$ of all observations have multiple fund managers. Only 85 funds use the same fund manager over the fund's life.

There are a number of different fund management styles. The traditional mandate given to a fund manager is a balanced mandate under which the fund manager manages across all asset 
classes, and then selects securities within each asset class. The asset allocation decision has a strategic component, in which the global mix of asset classes are considered based on long term expectations of expected returns and global macroeconomic factors. In the short term, fund managers may make tactical asset allocation decisions, moving away from the strategic asset allocation decision, to take advantage of short-term fluctuations in asset returns.

Within each asset class a fund manager will make security selection decisions. This may involve active fund management, based on better information or better investment skills of the fund manager, in order to earn a return above the efficiency frontier. As distinct from balanced fund management, the pension fund may employ specialist managers or apply specialist mandates to specific sectors, having made the asset allocation decision separately. An alternative to active management is passive fund management, whereby the fund manager adopts a stock selection strategy that tracks the market portfolio an appropriate index. Pension funds may also employ specialist fund managers who apply quantitative investment management techniques, such as programme trading, or use hedge funds

\section{Return Calculation Methods and Benchmarks}

Investors such as pension funds who have delegated their portfolio to a portfolio manager will want to assess the portfolio's performance in terms of its realized risk and returns characteristics. The return to a pension fund's investments over a period $(t, t+1)$, provided there are no net cash inflows into the pension fund during the period is defined as

$$
r_{i}=\frac{m v_{i, t+1}+d i v s_{i, t}-m v_{i, t}}{m v_{i, t}}
$$

where $r_{i}$ is the return on the pension fund over the period, divs $s_{i, t}$ are the dividends received by the pension fund from its investments at the end of the period, $m v_{i, t}$ is the market value of the fund at time $t$. However suppose that there are net inflows $N I_{i, t}$ representing cash coming into the fund, though contributions, and cash going out in the form of pensions. A mature pension fund, with a high percentage of pensioners to active members, is likely to have negative net inflows. We need to allow for these cash flows in the return calculation, since they do not reflect the investment performance of the fund manager. 


$$
r_{i}=\frac{m v_{i, t+1}+\operatorname{divs}_{i, t}-N I_{i, t}-m v_{i, t}}{m v_{i, t}}
$$

There are two methods for allowing for within-period cash-flows: time weighted return (TWR), and money weighted return (MWR). TWR calculates the return achieved from a time point immediately after each cash flow until the next cash flow and compounds the returns to get the total return. MWR treats the investment as a project with positive and negative cash flows, and calculate the internal rate of return (IRR) of these cash flows. The IRR is called the MWR when applied in this manner. In general TWR and MWR differ because TWR is a pure percentage return, taking no account of the size of the actual cash value on which the percentage is based;

The CFA Institute (formerly the AIMR) has developed a comprehensive set of Global Investment Performance Standards (GIPS), in order to promote a common set of guidelines for portfolio performance measurement: and these standards recommend the use of TWR in performance calculations. Although there may be times when the portfolio assessment would like to take account of the amount of funds under management, in which case the MWR would be more appropriate. So the moral is that in calculating returns ensure that cash inflows and outflows are appropriately allowed for, and then either use TWR or MWR consistently to compute returns.

Table 6 reports the average return on the median UK pension fund over the period 2994-2003 as 6.1 per cent per annum. Part of the investment return will be due to movements on the stock market as a whole. In order to isolate the performance of the fund manager, the performance of the investment portfolio may be separated from the return on an appropriate benchmark portfolio. One candidate benchmark is a stock market index such as the S\&P500, or the FTSE100. However this may be a poor proxy for the asset allocation of the whole pension fund, if the fund is invested in a variety of asset classes. Tables 7 and 8 illustrates the asset allocation of UK pension funds from 1993-2003, and of the pension funds of a number of major economies in 2003. Table 8 suggests that the asset allocation of pension funds is similar across countries: approximately 50 per cent in equities, 25 per cent in bonds, and the remainder in cash, property and other assets. There are some differences in the split between foreign and domestic equities and bonds, but table 7 shows how the median UK pension fund 
has moved towards its recent asset allocation: a substantial reduction in UK equities, partially offset by an increase in overseas equities, and a substantial increase in bonds.

Therefore in order to assess performance of the portfolio, we could use a market index appropriate to the particular asset class, such as in the second column of Table 6. However market indices still suffer from a number of problems. The sector market index may exhibit survivorship bias from assets that have been removed due to poor performance, so that returns on the index will be upward biased. It would not be possible to generate the returns on an index, by continuously replicating the exact asset composition of the index without incurring substantial trading costs. Bailey, Richards and Tierney (2001) point out that pension funds may hire fund managers with specific investment mandates which are related to the liabilities of the pension fund. The market index may not reflect the divergent style of the managers. Other alternative benchmarks are the median return of a sample fund managers in a similar asset class, or a normal portfolio. Bailey (1992) makes a number of criticisms of median managers including: the subjective selection of the sample; the different risks and styles between managers; the lack of transparency in such a benchmark and the difficulty in replicating the same investment strategy. Normal portfolios are customized benchmarks designed to reflect the style of an individual manager, but these may be difficult to implement, and are subject to manipulation from an underperforming fund manager. Blake (1998) and Blake and Timmermann (2002) suggest the use of liability-driven benchmarks. However this raises the issue of the valuation of pension liabilities, and it is unclear how to obtain the appropriate discount rate for valuing pension liabilities. ${ }^{3}$

\section{Risk Adjusted Portfolio Performance Measurement Measures}

In making the comparison in terms of realised returns it is important to make an adjustment for the risk of the portfolio. What is the appropriate measure of risk? If the portfolio is the only portfolio held by the pension fund then the total risk of the portfolio would be the measure of risk. If the portfolio is held along with a number of other portfolios, then the nondiversifiable risk of the portfolio will be the appropriate measure.

(a) Sharpe Measure: Excess Return to Variability

\footnotetext{
${ }^{3}$ Speed et al (2003) and Hill (2003) discuss the use of liability based benchmarks in the context of pension fund returns.
} 
To assess the portfolio returns Sharpe $(1966,1994)$ proposed computing $S$ for the portfolio under consideration and also for the benchmark portfolio.

$$
S=\left(r_{p}-r_{f}\right) / \sigma_{p}
$$

where $r_{p}$ is the return on the portfolio, $r_{f}$ is the risk-free rate and $\sigma_{p}$ is the standard deviation of the returns on the portfolio. The Sharpe measure uses the Capital Market Line as a benchmark and is appropriate for a pension fund that has invested its wealth in the one portfolio under consideration. Lo (2002) has examined the properties of the Sharpe Ratio taking account of estimation risk.

\section{(b) Excess Return to beta: Treynor Measure}

Treynor (1965) proposed using the Security Market Line as a benchmark and $T$ is appropriate for funds that have invested their wealth in a number of portfolios.

$$
T=\left(r_{p}-r_{f}\right) / \beta_{p}
$$

where $\beta_{\mathrm{p}}$ is the beta of the portfolio. Again to assess the performance of a portfolio, $\mathrm{T}$ is computed for both the portfolio and a benchmark.

\section{(c) Jensen Differential Performance Index}

Jensen (1968) proposed measuring the performance of a portfolio by its abnormal return above the Security Market Line

$$
\alpha_{p}=r_{p}-\left\{r_{f}+\beta_{p}\left(E r_{m}-r_{f}\right)\right\}
$$

where $E r_{m}$ is the expected return (sample average) on the market portfolio, and $\alpha_{p}$ is the Jensen- $\alpha$ measure of out-performance. Alternatively we may regress the excess return $\left(r_{p}-r_{f}\right)$ of a portfolio against the excess return on the market and interpret the intercept as the Jensen measure. The Jensen- $\alpha$ specifically evaluates the active fund management by the portfolio manager, as opposed to the passive fund management of investing in the risk-free asset and the market portfolio.

Although bother the Treynor and Jensen measures are based on the Security Market Line, when comparing two portfolios, they can give conflicting assessments of performance. This is because the Treynor measure evaluates a portfolio based on the excess return per unit of risk, measured by the portfolio beta. In contrast the Jensen-alpha measures the absolute excess return for the level of risk adopted by the portfolio. These three measures of portfolio performance can be interpreted as investment returns, in the following was. The Sharpe 
measure S shows the return per unit of volatility to the zero investment portfolio formed by borrowing $\$ 1$ and investing it in the portfolio. The Treynor measure $\mathrm{T}$ shows the return per unit of beta-risk to the zero investment portfolio formed by borrowing $\$ 1$ and investing it in the portfolio. The Jensen-alpha shows the return earned by the zero investment portfolio formed by selling short $\beta_{\mathrm{P}}$ dollars in the market portfolio and $\left(1-\beta_{\mathrm{P}}\right)$ dollars in the risk free asset and investing $\$ 1$ in the portfolio

The Jensen- $\alpha$ measure has the advantage that it can easily be extended to alternative asset pricing models, such as the Arbitrage Pricing Theory. The multi-factor Jensen- $\alpha$ with $n$ factors can be written as

$$
\alpha_{p}=r_{p}-r_{f}-b_{p 1} F_{1}-b_{p 2} F_{2}-\ldots-b_{p n} F_{n}
$$

where $F_{k}$ is the risk premium on the $n t h$ factor.

\section{d) Information Ratio}

The information ratio is similar to the Sharpe Ratio but compares the performance of a portfolio to its benchmark

$$
I=\left(r_{p}-r_{b}\right) / \sigma_{E R}
$$

Where $r_{p}$ is the average return for portfolio $p$ over some period, $r_{b}$ is the average return on a benchmark portfolio over the same period, so that $\left(r_{p}-r_{b}\right)$ is the excess return on the portfolio over the benchmark; $\sigma_{E R}$ is called the tracking error, and is the standard deviation of the excess returns during the period. The Information Ratio compares the return over the benchmark with the 'risk' taken - where risk is the tracking error, defined as the deviation from benchmark

\section{Problems with Performance Measurement}

a) The Market Index

A potential problem with the risk-adjusted performance measures outlined above, is that the benchmark used for comparison may be inappropriate. For example it is an unresolved question whether the CAPM is the correct asset pricing model that can explain the crosssectional distribution of asset prices in an economy [Fama and French (1996)]. Even if the correct asset pricing model is specified, Roll (1978) points out that the chosen index may not represent the entire universe of securities: in fact it is likely that equity indices such as the S\&P 500 will have a large capitalization bias. In this case the performance measure may be 
comparing the performance of the fund with a benchmark that itself is inefficient. Grinblatt and Titman (1993) suggest a method of assessing portfolio performance without requiring a benchmark, this involves comparing the performance of the selected assets in the portfolio, with a reference period when these same assets were not in the portfolio.

\section{b) Market Timing}

The original Jensen technique made no allowance for market timing abilities of fund managers when fund managers change the composition of their portfoilio on the basis of expected market movements. When portfolio managers expect the market portfolio to rise in value, they may switch from bonds into equities and/or they may invest in more high beta stocks. When they expect the market to fall they will undertake the reverse strategy: sell high beta stocks and move into "defensive" stocks. If managers successfully engage in market timing then, returns to the fund will be high when the market is high, and also relatively high when the market is low

If there was no market timing then a regression of $r_{i}-r_{f}$ against $r_{m}-r_{f}$ would produce points scattered around the solid line in figure 1 . If there is market timing, then the correct model specification, should be a different dotted line in the good and bad market conditions. A simple Jensen-alpha intercept will conclude that there is negative performance. If managers successfully market time, then a quadratic plot would prove a better fit (Treynor-Mazuy test). So a test of market timing is a significant value of $\gamma_{p}$ in the following regression, for the single factor model

$$
R_{p t}-r_{f}=\alpha_{p}+\beta_{p}\left(R_{m t}-r_{f}\right)+\gamma_{p}\left(R_{m t}-r_{f}\right)^{2}+\varepsilon_{p t}
$$

An alternative test of market timing for the single factor model suggested by MertonHenriksson is

$$
R_{p t}-r_{f}=\alpha_{p}+\beta_{p}\left(R_{m t}-r_{f}\right)+\delta_{p}\left(R_{m t}-r_{f}\right)^{+}+\eta_{p t}
$$

where $\left(R_{m t}-r_{f}\right)^{+}=\operatorname{Max}\left(0, R_{m t}-r_{f}\right)$. The market timing test is easily extended to a multifactor framework, assessing the timing on each of the style components.

\section{d) Conditional Performance Evaluation}

In order to distinguish fund managers' skills from simply taking advantage of predictable market or factor movements, Ferson and Schadt (1996) advocate allowing for the benchmark 
parameters to be conditioned on economic conditions. Allowing the market parameters to be time-varying, the Jensen regression becomes

$$
R_{i t}-r_{f t}=\alpha_{i}+\beta_{i}\left(Z_{t-1}\right)\left(R_{m t}-r_{f t}\right)+\gamma_{i} F_{t}+\varepsilon_{i t}
$$

where $\mathrm{Z}_{\mathrm{t}-1}$ is a vector of instruments for the information available at time $\mathrm{t}$ (and is therefore specified as t-1) and $\beta_{i}\left(Z_{t}\right)$ are time conditional betas, and their functional form is specified as linear

$$
\beta_{i}\left(Z_{t}\right)=b_{0}+B^{\prime} z_{t-1}
$$

where $\mathrm{Z}_{\mathrm{t}-1}=\mathrm{Z}_{\mathrm{t}-1}-\mathrm{E}(\mathrm{Z})$ is a vector of deviations of the $\mathrm{Zs}$ from their unconditional means. Implementing this approach involves creating interaction terms between the market returns and the instruments. Typical instruments used are: lagged treasury bill rate, dividend yield, default premium (difference between low and high quality corporate bonds), slope of the term structure (difference between long and short run government bond yields).

\section{d) Style-adjusted performance}

The benchmark portfolio can be a single index or because investment style is important, a 'customised' benchmark can be developed specifically for the portfolio in question [Daniel et al (1997)]. For example, if the portfolio holds on average 20\% US government bonds, $80 \%$ US equities, we may form a customised benchmark as 0.8 x S\&P500 + 0.2 x Merrill Lynch Government Bond Index. Usually the customised benchmark is based on an effective mix style analysis [Sharpe (1992)]. This is achieved by performing an 'effective mix' style analysis on the fund and finding the style exposures. For example, suppose a regression is run on the portfolio returns against various factors, and suppose the following factor-loadings are estimated: 0.4 for large value stock portfolio; 0.2 for growth stock portfolio; 0.3 for small cap portfolio; and 0.1 for government bond. Then we can form a customised benchmark for the fund as $0.4 *$ Large $+0.2 *$ growth $+0.3 *$ Small cap $+0.1 *$ Bonds

\section{Evidence on Investment Performance}

The early evidence on the performance of mutual funds in the US found that simple tests of abnormal performance did not yield significant returns. Jensen (1968) examined the performance of 115 mutual funds over the period 1955-1964, using the Security Market Line as the basis for a comparison. Jensen's technique is to regress the excess returns on the individual fund (above the risk free rate), against the excess return on the market $\left(\mathrm{R}_{\mathrm{mt}}-\mathrm{r}_{\mathrm{ft}}\right)$

$$
R_{i t}-r_{f t}=\alpha_{i}+\beta_{i}\left(R_{m t}-r_{f t}\right)+\varepsilon_{i t}
$$


for each fund $i$ over the $t$ data periods, and save the coefficients $\alpha_{i}$ and $\beta_{i}$. Under the null hypothesis of no-abnormal performance the $\alpha$ coefficient should be equal to zero. For each fund we may test the significance of $\alpha$ as a measure of that funds abnormal performance. In addition we may test for overall fund performance, by testing the significance of the mean $\alpha$.

$$
\bar{\alpha}=\frac{1}{N} \sum_{i=1}^{N} \alpha_{i}
$$

The appropriate t-statistic is

$$
t=\frac{1}{\sqrt{N}} \sum_{i=1}^{N} \frac{\alpha_{i}}{S E\left(\alpha_{i}\right)}
$$

He then examines the abnormal return for each fund net of expenses. Jensen found that the average abnormal return across funds was approx $-1 \%$ per annum: if expenses were added back into the gross return, average abnormal return was approx. zero. Hence Jensen's conclusions were that market professionals do not appear to be able to beat the market.

Applying this same methodology to the average performance of pension funds, Ippolito and Turner (1987) examined returns on 1,526 US pension funds and find underperformance relative to the S\&P500 Index. Lakonishok, Shleifer and Vishney (1992) provide evidence on the structure and performance of the Money Management Industry in the US in general, but focus on the role of pension funds, examining 769 pension funds, with total assets of $\$ 129$ billion at the end of 1989. They find the equity performance of funds under-performed the S\&P 500 by $1.3 \%$ per year throughout the eighties. They emphasise that although there is a long literature on the under-performance of mutual funds, pension funds also under-perform relative to mutual funds on average. Coggin, Fabozzi and Rahman (1993) investigate the investment performance of a random sample of 71 US equity pension fund managers for the period January 1983 through December 1990, and find that the average selectivity measure is positive and average timing ability is negative. Though both selectivity and timing are sensitive to the choice of benchmark when management style is taken into consideration. For example they find that funds that target value strategies yielded outperformance of 2.1 per cent per annum, but funds that adopted growth strategies underperformed by -0.96 per cent.

In the UK Blake, Lehmann, \& Timmermann, (1999) examine the asset allocations of a sample of 364 UK pension funds who retained the same fund manager over the period 19861994. They find that the total return is dominated by asset allocation. Average return from 
stock selection is negative, and average return to market timing very negative. In one asset class, UK equity managers are comparatively good at selecting equities, but only $16 \%$ of sample beat peer group average. Thomas and Tonks (2001) investigate the performance of the UK equity portfolios of 2,175 segregated UK pension funds over the period 1984-97, and the results are presented in Table 9. They find that over the whole period and across all funds average outperformance was not very different from zero, and there were negative return to market timing, though the significance of selectivity increased with the addition of the market timing variable. The distribution of the Jensen-alphas across funds is given in figure 2. Gregory and Tonks (2004) examine the performance of individual personal pensions (exempt unit trusts) in the UK 1980-2000. They examine those personal pension schemes that invest predominantly in UK equities, and in table 10 report that average performance is not significantly different from zero.

\section{Persistence in Investment Performance}

Although on average fund managers do not outperform, in any sample there is a distribution to the performance as in figure 1, and more recently research on performance measurement has investigated whether the outperformers in the sample continue to outperform in the future. Grinblatt and Titman (1992) find that differences in mutual fund performance between funds persist over 5-year time horizons and this persistence is consistent with the ability of fund managers to earn abnormal returns. Carhart (1997) demonstrates that common factors in stock returns (including a momentum factor) and investment expenses explain persistence in equity mutual funds' mean and risk-adjusted returns. The only significant persistence not explained, is concentrated in strong underperformance by the worst return mutual funds. His results do not support the existence of skilled or informed mutual fund portfolio managers. There are a number of tests for persistence, and recently Carpenter and Lynch (1999) have assessed the power of these difference tests particularly in the presence of different types of survivorship bias. Carpenter and Lynch classify persistence tests into two types: performance ranked portfolio strategies, and contingency tables.

Performance ranked portfolio tests sort fund manager each year into portfolios based on past performance, and then form portfolios of the top and bottom managers (by decile or quintile). The equally weighted average portfolio abnormal return of the top and bottom portfolios over the subsequent evaluation period is then evaluated. These procedures are followed for overlapping periods throughout the full period of the dataset, and the difference between the 
average abnormal return on the series of top and bottom portfolios are computed. From their simulations Carpenter and Lynch find that the persistence test based on a t-statistic of the difference between the performance of the top and bottom portfolio managers is the best specified under the hypothesis of no persistence, and the most powerful against the alternatives considered. These persistence tests can be computed on the basis of alternative ranking and evaluation time periods, since it may be the case that persistency is only apparent at particular time intervals.

Contingency tables classify funds as winners or losers in each of two consecutive time periods, and examines the distribution of winner-loser combinations. Lakonishok et al (1992) in their study of 769 all equity pension funds, undertakes a contingency analysis with funds divided into quartiles, and concludes that evidence of persistence is weak since there is only a 26 per cent probability of repeat top quartile performance. In the UK, Brown, Draper and McKenzie (1997) and Blake, Lehmann, \& Timmermann, (1999) have examined consistency in UK occupational pension fund performance. Both studies find only weak evidence of persistence in performance. In constructing their data samples, both the Brown et al (1997) and Blake et al (1999) studies of UK pension funds specify that the pension fund have the same single fund manager over the length of their respective samples. Tonks (2005) argues that this specification of the dataset may have induced survivorship bias in these data samples, since Grinblatt and Titman (1992) and Hendricks, Patel and Zeckhauser (1993) have argued that if fund survival depends on average performance over several periods, then survivorship induces spurious reversals: first-period losers must subsequently win in order to survive, and this biases persistence downwards. Tonks (2005) examines persistence in pension fund manager performance using data on UK occupational pension funds irrespective of whether they change manager. He finds strong evidence of persistence in abnormal returns generated by fund managers over one year time horizons. He found that the returns on a zero investment portfolio of a long position in a portfolio of fund managers that performed well over the previous 12 months and a short position in a portfolio of fund managers that performed poorly, would have yielded an annualised abnormal return of $1.56 \%$. He then compares his sample with a restricted sample that imposes the Brown et al (1997), and Blake et al (1999) criteria that specify that the pension fund has the same fund manager over the length of their respective samples. With the restricted sample he finds that the evidence on persistence is weaker. Gregory and Tonks (2004) in their study of personal pension 
funds also examine persistence in performance of these pension schemes and identifies negative persistent at short horizons, but at time-intervals of six months to one year finds significant positive persistence, though this positive persistence weakens at longer time intervals.

\section{Conclusions}

This paper has provided a survey of the pension fund management industry and how it relates and interacts with individual and occupational private pension funds. We have focused on the performance of pension funds whose assets are managed by fund managers. In a funded scheme the pension paid to a retired person will depend on the accumulated value of the assets in the pension fund at retirement. This is clearly the case for a defined contribution scheme where the relationship between the value of the fund and the pension is explicit. But this same annuitisation is implicit in a defined benefit scheme, since although there may be some risk sharing across generations, ultimately the defined benefit scheme is only able to pay out a pension that is a proportion of the value of the assets in the scheme. The value of the pension fund will increase over time due to contributions and the investment returns on the fund. These investment returns depend on the asset allocation and portfolio decisions of fund managers. Small changes in the investment returns compound up to large changes in the value of the pension fund at retirement The evidence on fund manager performance is that on average they do not add very much value over and above a passive strategy of investing in the market index. However this average disguises the fact that some fund managers perform well, and others perform poorly. Identifying and understanding the persistence of the poor performance of some fund managers is an important issue in the pensions area. 


\section{References}

Bailey, J.V., T.M.Richards and D.E.Tierney (1990) "Benchmark portfolios and the Manger/Plan Sponsor Relationship", in Current Topics in Investment Management (New York: Harper \& Row)

Bailey, J.V. (1992) “Are Manager Universes Acceptable Performance Benchmarks”, Journal of Portfolio Management, vol. 18, no. 3, 9-13.

Bhattacharya, S. and Pfleiderer, P., 1985, Delegated Portfolio Management, Journal of Economic Theory 36, 1-25

Blake, D. (2003) Pension Schemes and Pension Funds in the UK (Oxford University Press, $2^{\text {nd }}$ edition)

Blake, D. (1998), "Measuring the Performance of Pension Funds using Liability-Driven Performance Attribution", Journal of Pensions Management, vol. 3, 105-109.

Blake, D., B. Lehmann and A. Timmermann. 1999. Asset allocation dynamics and pension fund performance. Journal of Business 72, 429-461.

Blake, D. and A. Timmerman. 2002, "Performance benchmarks for institutional investors", in in J. Knight and S. Satchell (eds.) Performance Measurement in Finance, (ButterworthHeinemann, 2002), pp. 342-364.

Brinson, G.P., Hood, L.R. and Beebower, G.L. (1986) Determinants of portfolio performance, Financial Analysts Journal, July/August, 39-48.

Brown, G. P. Draper and E. McKenzie. 1997. Consistency of UK pension fund performance. Journal of Business Finance and Accounting 24, March, 155-178.

Carpenter, J.N., and A.W. Lynch. 1999. Survivorship bias and attrition effects in measures of performance persistence. Journal of Financial Economics 54, 337-374.

Carhart, M. 1997. On persistence in mutual fund performance. Journal of Finance 52, 57-82.

Coggin, T.D., F.J. Fabozzi, and S. Rahman. 1993. The investment performance of US equity pension fund managers: an empirical investigation. Journal of Finance 48, 1039-55.

Daniel, K., M. Grinblatt, S. Titman and R. Wermers (1997) "Measuring Mutual Fund Performance with Characteristic Based Benchmarks", Journal of Finance July 1997

Davis, E.P. (1995) Pension Funds: Retirement-Income Security, and Capital Markets: An International Perspective, (Clarendon Press, Oxford)

Davis, E.P. (1998) "Pension rund reform and European financial markets" LSE Financial Markets Group Special Paper no. 107

Davis, E.P and B. Steil (2001) Institutional Investors (MIT Press) 
Del Guercio and Tkac (2002) "The determinants of the flow of funds of managed portfolios: mutual funds vs pension funds", Journal of Financial and Quantitative Analysis, vol. 37, no. $4,523-557$

Dilnot, A. and P. Johnson (1993) The Taxation of Private Pensions (Institute for Fiscal Studies, |London)

Fama, E. and K. French (1996) "The CAPM is Wanted, Dead or Alive", Journal of Finance, vol. 51, 1947-1958.

Ferson, W. and R.W.Schadt (1996) Measuring Fund Strategy and Performance in Changing Economic Conditions", Journal of Finance, vol. 51, 425-462.

Franks, J., C. Mayer and L.C. da Silva (2003) Asset Management and Investor Protection: An International Analysis (Oxford University Press)

Gregory, A. and I. Tonks (2004) "Performance of Personal Pension Schemes in the UK" UBS/FMG Discussion Paper, No. 486, March 2004

Grinblatt, M. and S. Titman. 1992. Persistence in mutual fund performance. Journal of Finance 47, 1977-84.

Grinblatt, M. and Titman, S.D. (1993) Performance measurement without benchmarks: an examination of mutual fund returns, Journal of Business, 66(1), 47-68.

Hendricks, D., J. Patel and R. Zeckhauser. 1993. Hot hands in mutual funds: short run persistence of relative performance, 1974 - 1988. Journal of Finance 48, 93-130.

Henriksson, R. and Merton, R. (1981) On market timing and investment performance. II. Statistical procedures for evaluating forecasting skills, Journal of Business, 54(4), 513-533.

Hill, J. (2003) Submission on the Relationship between Pension Assets and Liabilities, (Staple Inn Actuarial Society, 2003).

Ippolito, R.A. and J.A. Turner. 1987. Turnover, fees and pension plan performance.

Financial Analysts Journal 43, 16-26.

Jensen, M.C. (1968) "The performance of mutual funds in the period 1945-1964", Journal of Finance, vol. 23, no. 2, 389-416.

Lakonishok, J.A., A. Shleifer and R.W. Vishny. 1992. The structure and performance of the money management industry. Brookings Papers on Economic Activity, 339-391.

Lo, A. W., (2002) “The Statistics of Sharpe Ratios”, Financial Analysts Journal, vol. 58, no. 4, (July/August 2002), 36-52

Myners, P. 2001. Report on institutional investment H.M. Treasury.

Occupational Pensions Regulatory Authority. 2001. Pensions registry. 
Palacios, R. and M. Pallares-Miralles (2000) “The Social Protection Advisory Service”, World Bank

Roll, R. (1978) Ambiguity when performance is measured by the securities market line, Journal of Finance, 33, 1051-1069.

Sandler, R. (2002) Medium and Long-Term Retail Savings in the UK: A Review, (HM Treasury)

Sharpe, W.F. (1966) “Mutual Fund Performance", Journal of Business, vol. 39, no. 1, part 2, 119-138.

Sharpe, W.F. (1992) "Asset allocation, management style and performance measurement", Journal of Portfolio Management, Winter, 7-19.

Sharpe, W.F. (1994) “The Sharpe Ratio", Journal of Portfolio Management, vol 21, no 1, 4959.

Speed, C., D. Bowie, J. Exley, M. Jones, R. Mounce, N. Ralston, T. Spiers and H. Williams (2003) "Note on the Relationship between Pension Assets and Liabilities", (Staple Inn Actuarial Society, 2003)

Stoughton, N. M. (1993) "Moral Hazard and the Portfolio Management Problem", Journal of Finance, vol. 47, 2009-2028

Thomas, A. and I. Tonks. 2001. Equity performance of segregated pension funds in the UK. Journal of Asset Management 1 no. 4, 321-343

Tonks, I. (2002) "Measuring Pension Fund Performance in the UK", in J. Knight and S. Satchell (eds.) Performance Measurement in Finance, (Butterworth-Heinemann, 2002), pp. 342-364.

Tonks, I. (2005) "Performance Persistence of Pension Fund Managers", Journal of Business, vol. 78, no. 6, November 2005.

Treynor, J.L. (1965) "How to rate management of investment funds", Harvard Business Review, (43), January/February, 63-75.

Treynor, J.L. and Mazuy, F. (1966) Can mutual funds outguess the market?, Harvard Business Review, (44), 131-136. 
Table 1: Private Pension Funding in Major Developed Countries in 1996

\begin{tabular}{lrr}
\hline & US \$bn & \% of \\
& & GDP \\
\hline Belgium & 11 & 4 \\
Canada & 213 & 45 \\
Denmark & 38 & 22 \\
Finland & 18 & 14 \\
France & 69 & 5 \\
Germany & 137 & 6 \\
Ireland & 32 & 43 \\
Italy & 32 & 3 \\
Japan & 943 & 22 \\
Netherlands & 349 & 89 \\
Spain & 22 & 4 \\
Sweden & 38 & 33 \\
UK & 966 & 76 \\
US & 4763 & 62 \\
EU Total & 1730 & 21 \\
\hline
\end{tabular}

Source: Davis (1998)

Table 2: Assets under Management for eight countries 1999 (Euro billion)

\begin{tabular}{llll}
\hline Country & Pension Funds & $\begin{array}{l}\text { Insurance } \\
\text { Companies }\end{array}$ & Mutual Funds \\
\hline France & 66 & 830 & 705 \\
Germany & 129 & 673 & 515 \\
Ireland & 47 & 32 & 150 \\
Italy & 65 & 169 & 412 \\
Netherlands & 397 & 220 & 83 \\
Spain & 32 & 62 & 219 \\
UK & 1270 & 1266 & 345 \\
Total & 2006 & 3252 & 2429 \\
Euro-7 & & & 6388 \\
\hline USA & 7225 & 2403 &
\end{tabular}

Source: Franks, Mayer \& da Silva (2003) 
Table 3: Institutionalisation of the UK Equity Market to 1999.

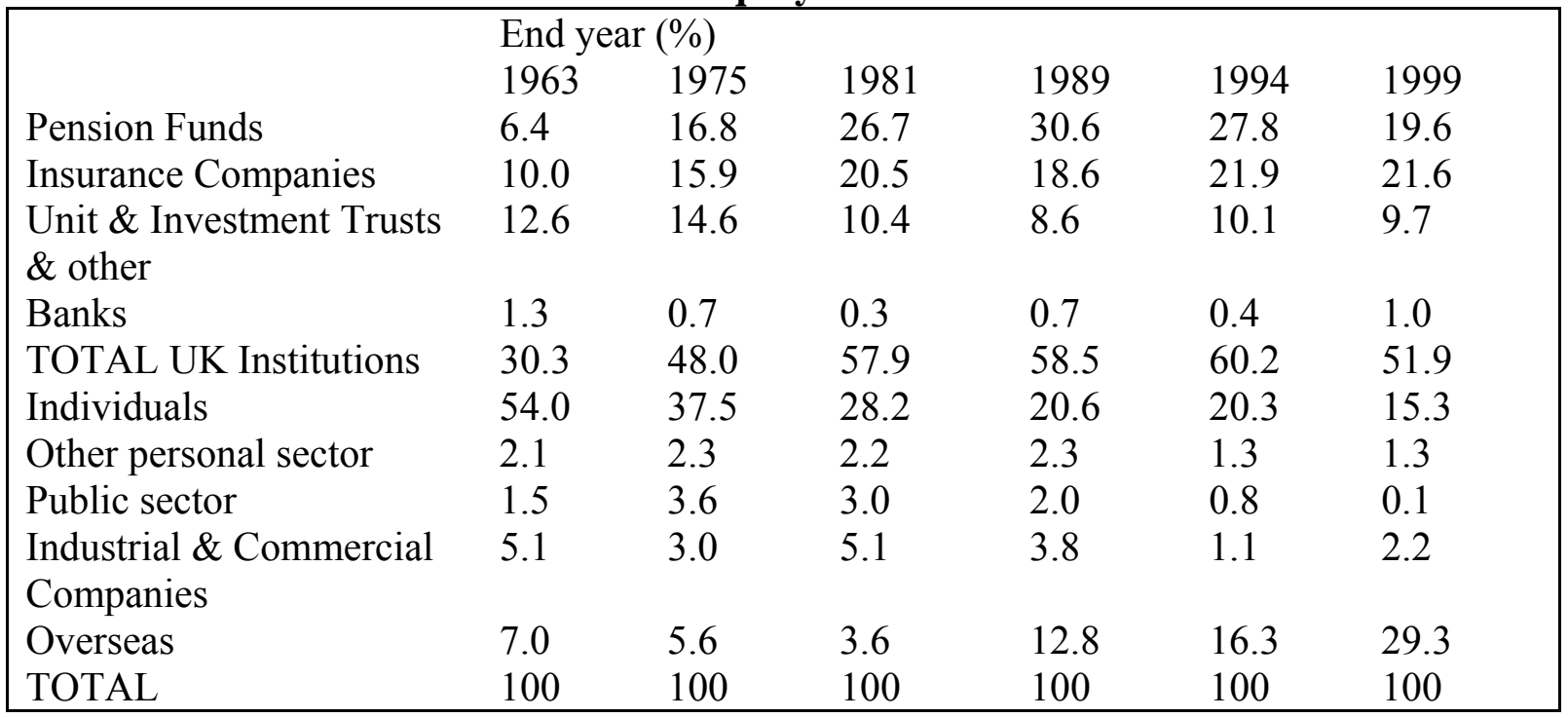

Source Myners' Report 2001, from ONS 'Share Ownership: A Report on the Ownership of Shares at 31/12/99', p. 8

Table 4: Fund Management fees charged in different countries for a $£ 100$ million mandate

\begin{tabular}{|l|l|l|l|l|l|l|l|l|}
\hline \multicolumn{9}{|l|}{ Basis Points per annum } \\
\hline & Canada & \multicolumn{2}{l|}{ UK } & Australia & \multicolumn{2}{l|}{ US } \\
& Equities & $\begin{array}{l}\text { Fixed } \\
\text { Interest }\end{array}$ & Equities & $\begin{array}{l}\text { Fixed } \\
\text { Interest }\end{array}$ & Equities & $\begin{array}{l}\text { Fixed } \\
\text { Interest }\end{array}$ & Equities & $\begin{array}{l}\text { Fixed } \\
\text { Interest }\end{array}$ \\
\hline Upper Quartile Fee & 28 & 22 & 48 & 23 & 47 & 22 & 50 & 30 \\
\hline Median Fee & 24 & 18 & 40 & 18 & 44 & 19 & 42 & 26 \\
\hline Lower Quartile Fee & 21 & 16 & 30 & 17 & 40 & 18 & 33 & 23 \\
\hline
\end{tabular}

Source: Frank Russell quoted in Myners' Report (2001)

Table 5: Distribution of Managers Across Pension Funds by Category of Manager

\begin{tabular}{lrrrrr}
\hline Fman category & \multicolumn{3}{c}{ Overall } & \multicolumn{3}{c}{ Between Funds } & Within Funds \\
\hline & Freq & $\%$ & Freq. & $\%$ & $\%$ \\
\hline Multi-manager & 17,299 & 29.07 & 659 & 30.3 & 78.10 \\
1RMan & 6,410 & 10.77 & 244 & 11.22 & 81.04 \\
2RMan & 3,318 & 5.58 & 184 & 8.46 & 59.55 \\
3RMan & 2,881 & 4.84 & 116 & 5.33 & 73.40 \\
4RMan- & 13,758 & 23.14 & 681 & 31.31 & 68.16 \\
17RMan & & & & & \\
18RMan- & 15,595 & 26.22 & 965 & 44.65 & 58.84 \\
188RMan & & & & & \\
$\Delta$ Man & 248 & 0.42 & 225 & 10.34 & 2.64 \\
\hline Total & 59,509 & 100.0 & 3,074 & 141.33 & 63.43 \\
& & & $(\mathrm{n}=2,175)$ & & \\
\hline
\end{tabular}

Source: Tonks (2005). Sample consists of 2,175 pension funds $1984-97$ with 59,509 quarterly observations, with 190 categories of fund manager. Total within $=(659 * 78.1+244 * 81.04+\ldots \ldots) / 3,$.074 ; 'n'RMan denotes ' $n$ 'th ranked fund manager by frequency of observations. " denotes that each of these fund managers had greater than $1 \%$ of the overall frequency. 
Table 6: Average Annual Returns on Median UK Pension Fund by Asset Class 1994-2003 Median Pension Fund Return (\%) Index Return 1994-2003

(\%) 1994-2003 Index Definition

$\begin{array}{lr}\text { UK Equities } & 6.3 \\ \text { Overseas Equities } & 3.4 \\ \text { UK Gilts } & 7.1 \\ & \\ \text { Overseas Bonds } & 4.9 \\ \text { UK Index-Linked } & 6.5 \\ \text { Property } & 11.2 \\ \text { TOTAL FUND } & 6.1\end{array}$

6.1 FTSE All-Share

5.3 FTSEAll-World Ex-UK

7 FTSE A All Stocks Gilts JP Morgan (Global Ex-UK)

4.7 Traded

6.5 FTSE A ILG

9.8 CAPS Property

Source: RussellMellonCAPS Fund Returns 2004

Table 7: Average Asset Allocation across UK Pension Funds 1993-2003

As at 31 December

$\begin{array}{lrrrrrrrrrrr}\text { (\%) } & 1993 & 1994 & 1995 & 1996 & 1997 & 1998 & 1999 & 2000 & 2001 & 2002 & 2003 \\ & & & & & & & & & & & \\ \text { UK Equities } & 57.3 & 56.0 & 54.9 & 54.7 & 54.3 & 52.0 & 53.6 & 51.0 & 47.4 & 43.4 & 41.5 \\ \text { Overseas Equities } & 24.4 & 23.0 & 22.0 & 21.0 & 18.6 & 18.9 & 22.8 & 22.5 & 25.0 & 25.1 & 26.7 \\ \text { UK Bonds } & 4.8 & 6.1 & 7.4 & 7.9 & 9.4 & 11.3 & 10.3 & 12.8 & 14.8 & 18.2 & 19.4 \\ \text { Overseas Bonds } & 4.7 & 4.6 & 4.9 & 3.7 & 4.0 & 4.6 & 3.9 & 3.7 & 2.9 & 2.1 & 1.1 \\ \text { Index-Linked } & & & & & & & & & & & \\ \text { Bonds } & 3.0 & 3.8 & 3.8 & 3.9 & 4.1 & 4.0 & 4.0 & 5.0 & 5.7 & 7.1 & 7.5 \\ \text { Cash } & 3.5 & 3.7 & 4.6 & 6.6 & 7.5 & 7.2 & 3.5 & 3.2 & 2.3 & 2.0 & 1.6 \\ \text { Property } & 1.9 & 2.5 & 2.1 & 2.0 & 1.9 & 1.9 & 1.7 & 1.7 & 1.8 & 2.0 & 2.0 \\ \text { Other } & 0.4 & 0.3 & 0.3 & 0.2 & 0.2 & 0.1 & 0.2 & 0.1 & 0.1 & 0.1 & 0.2 \\ & & & & & & & & & & & \\ \text { TOTAL FUND } & 100.0 & 100.0 & 100.0 & 100.0 & 100.0 & 100.0 & 100.0 & 100.0 & 100.0 & 100.0 & 100.0\end{array}$

Source: RussellMellonCAPS 2004.

Table 8: Average Asset Allocation of Occupational Pension Funds in Major Markets 2003

$\begin{array}{lrrrrrrrr}\begin{array}{l}(\%) \\ \text { Domestic }\end{array} & \text { Australia } & \text { Japan } & \text { Netherlands } & \text { Sweden } & \text { Switzerland } & \text { UK } & \text { US } & \text { Average } \\ \begin{array}{l}\text { Equities } \\ \text { Overseas }\end{array} & 31 & 27 & 7 & 21 & 12 & 39 & 48 & 26 \\ \begin{array}{l}\text { Equities } \\ \text { Domestic }\end{array} & 22 & 17 & 36 & 16 & 13 & 28 & 14 & 21 \\ \begin{array}{l}\text { Bonds } \\ \text { Overseas }\end{array} & 17 & 32 & 8 & 29 & 30 & 12 & 33 & 23 \\ \begin{array}{l}\text { Bonds } \\ \text { Cash }\end{array} & 5 & 13 & 32 & 26 & 16 & 3 & 1 & 14 \\ \begin{array}{l}\text { Property } \\ \text { Other }\end{array} & 12 & 5 & 4 & 2 & 10 & 3 & 1 & 4 \\ \quad \text { TOTAL } & 7 & 5 & 5 & 6 & 15 & 6 & 2 & 7 \\ \text { FUND } & 100 & 100 & 100 & 100 & 100 & 100 & 100 & 100\end{array}$

Source UBS Pension Fund Indicators, 2004 
Table 9: Performance Evaluation of UK Pension Funds 1983-97

\begin{tabular}{lllll}
\hline $\begin{array}{l}\text { No. } \\
\text { Funds }\end{array}$ & $\alpha$ & $\alpha$ t-stat & $\begin{array}{c}\delta \text { (Market } \\
\text { Timing) }\end{array}$ & $\delta$ t-stat \\
\hline
\end{tabular}

Panel A: CAPM benchmark

Average values

No. coeffs $>0$

No. of signif. Coeffs.

Treynor-Mazuy:

Average Values
1714

0.00017

898

Merton-Henriksson:

Average values

Panel B: 3-factor benchmark

Average values

No. coeffs $>0$

No. of signif. Coeffs.

Source: Thomas and Tonks (2001) and Tonks (2002)

$1714 \quad 0.0001 \quad 4.526$

142

Table 10: Performance of UK Personal Pensions 1980-2000

\begin{tabular}{lrrrrr}
\hline \multicolumn{1}{c}{$\begin{array}{c}\text { No. } \\
\text { Funds }\end{array}$} & $\alpha$ & $\alpha$ t-stat & $\begin{array}{c}\delta \text { (Market } \\
\text { Timing) }\end{array}$ & $\delta$ t-stat \\
\hline $\begin{array}{l}\text { Panel A: CAPM benchmark } \\
\text { Average values }\end{array}$ & 399 & -0.00013 & -6.43 & & \\
$\begin{array}{l}\text { Average Values } \\
\text { Panel B: 3-factor benchmark }\end{array}$ & 399 & 0.00033 & -1.07 & -0.1538 & -14.12 \\
$\begin{array}{l}\text { Average values } \\
\text { Average values }\end{array}$ & 399 & 0.00029 & -1.68 & & \\
Source: & 399 & 0.00030 & 0.68 & 0.1081 & -7.75
\end{tabular}

Source: Gregory and Tonks (2004) 
Figure 1: Illustrating the Problem of Market Timing

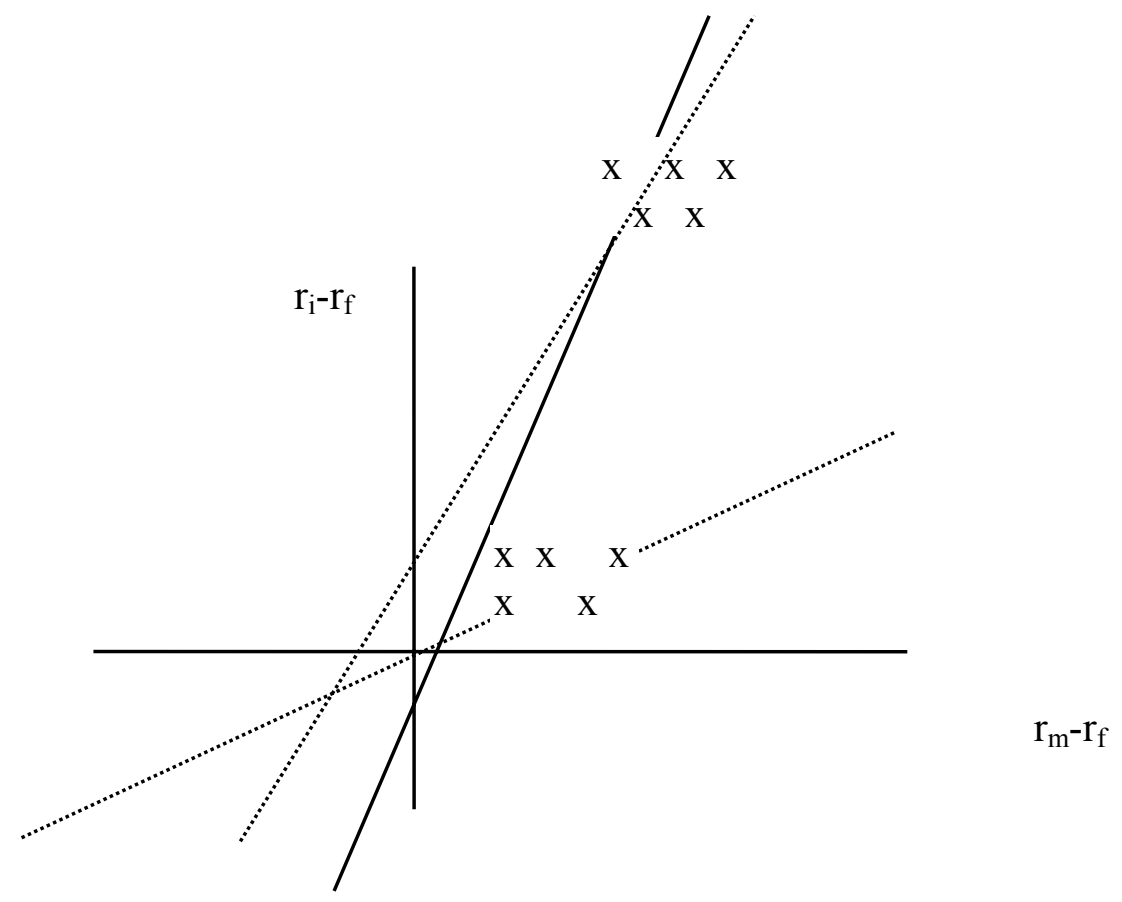

Figure 2: Evidence on performance of pension funds Thomas and Tonks (2001)

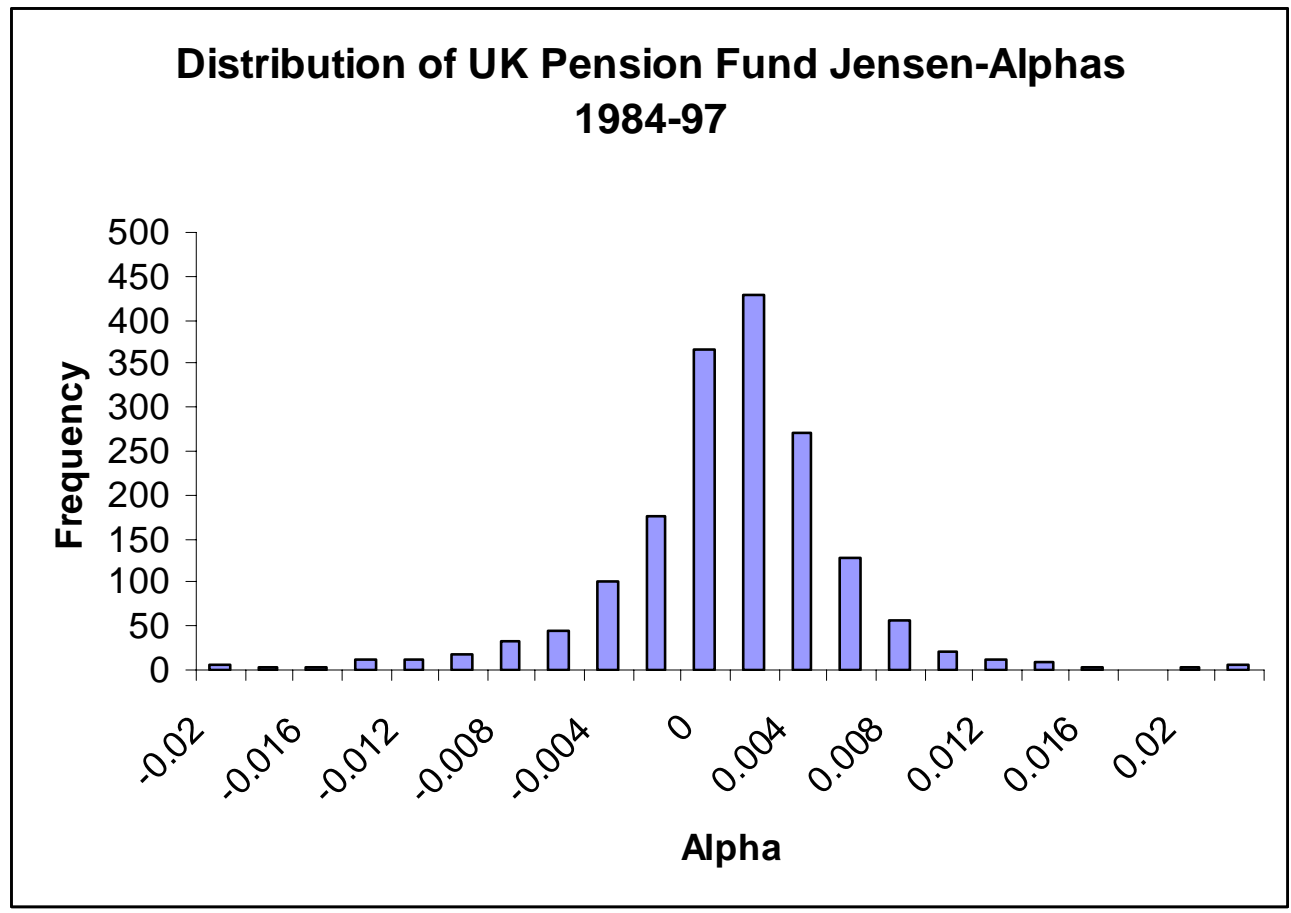


